\title{
Distribution of Cereal Cyst Nematodes (Heterodera avenae and H. filipjevi) in Eastern Washington State
}

\author{
Nuan Wen, ${ }^{1}$ Yvonne Manning-Thompson, ${ }^{1}$ Kimberly Garland-Campbell, ${ }^{2}$ and Timothy Paulitz ${ }^{2, \dagger}$ \\ ${ }^{1}$ Department of Crop and Soil Sciences, Washington State University, Pullman, WA 99164-6420, U.S.A. \\ ${ }^{2}$ USDA-ARS, Wheat Health, Genetics and Quality Research Unit, United States Department of Agriculture, Pullman, WA \\ 99164-6420, U.S.A.
}

\begin{abstract}
Cereal cyst nematodes (CCN; Heterodera avenae and H. filipjevi), cause substantial worldwide yield loss in small grain cereals such as wheat, barley, and oat. H. avenae was first detected in the United States in western Oregon in 1974 and had spread to northeast Oregon by the mid-1980s. Although H. avenae was detected in eastern Washington in 1984, extensive infestations were not recognized until 2010. H. filipjevi, first detected in Oregon in 2008, was found in eastern Washington in 2014. To gain more information about the distribution of these two species, an extensive survey was undertaken in eastern Washington, and methods were developed to distinguish species using DNA se-

the ribosomal internal transcribed spacers (ITS) and/or 28S ribosomal RNA (rRNA) genes. The sequences were compared in the GenBank database in the National Center for Biotechnology Information (NCBI) to identify species. The results show that $H$. filipjevi is primarily confined to southern Whitman County, WA; and H. avenae has a wider distribution across the higher precipitation annual cropping area of eastern Whitman County. Knowledge of species identification is critical for deployment of host resistance as an effective means of management, since resistance genes for one species of $\mathrm{CCN}$ may not be effective against the other.
\end{abstract} quencing of single cysts. In this study, we surveyed 356 wheat and barley fields in eastern Washington from 2007 to 2017. CCN from the infested locations were identified to species level by sequencing
Keywords: cereal cyst nematode (CCN), Heterodera filipjevi, Heterodera avenae, distribution, molecular species identification
Small grain cereals, including wheat, barley, and oat, are among the most prominent staple crops and nutrition sources for humans and livestock. The global demand for small grain cereals is increasing by $1 \%$ annually, and by 2050 , the production of wheat (Triticum aestivum L.), the third most produced crop after maize and rice, needs to be increased by $60 \%$ to fulfill the demand (Alexandratos and Bruinsma 2012; Diekmann 2009). Cereal cyst nematodes (CCN; Heterodera species) cause substantial yield loss in wheat, making the management of $\mathrm{CCN}$ a potential strategy to increase yield. The percentage of yield loss caused by $\mathrm{CCN}$ is difficult to generalize due to the variation in $\mathrm{CCN}$ distribution, species, pathotypes, density, crop variety, management practices, and other biotic and abiotic factors. Documented yield loss ranging from 15 to $92 \%$, and most commonly around 50\%, has been reported from Australia, Saudi Arabia, China, India, Tunisia, Pakistan, Israel, Norway, Syria, and the United States (Hassan et al. 2010; Holgado et al. 2003; Ibrahim et al. 1999; Maqbool 1988; Mathur et al. 1986; Meagher 1972; Mor et al. 1992; Namouchi-Kachouri et al. 2007; Peng et al. 2007; Smiley et al. 1994).

${ }^{\dagger}$ Corresponding author: T. Paulitz; timothy.paulitz@ars.usda.gov

Funding: Funding support for this project was provided by the Washington Grains Commission project no. 3061-7667.

*The $e$-Xtra logo stands for "electronic extra" and indicates that four supplementary tables are published online.

The author(s) declare no conflict of interest.

Accepted for publication 31 March 2019.

This article is in the public domain and not copyrightable. It may be freely reprinted with customary crediting of the source. The American Phytopathological Society, 2019.
Current control strategies include fallow and rotation with non$\mathrm{CCN}$ host crops, chemical nematicides, biological control using nematophagous fungi and bacteria, and breeding for resistant cultivars. Fallow and rotation in most cases are not as profitable where wheat is the primary cash crop; chemical nematicides are being withdrawn from use because of the negative impact on the environment; and biological control has not been exploited and promoted at a commercial scale. Thus, breeding for resistant cultivars remains the most efficient and cost-effective way to reduce $\mathrm{CCN}$ damage. Twelve $\mathrm{CCN}$ resistance genes $(\mathrm{Cre}$ ) have been identified to date: Cre 1, 2, $3,4,5,6,7,8, R, X, Y$, and $Z$. All have been introgressed into hexaploid wheat (Asiedu et al. 1990; Barloy et al. 2007; Delibes et al. 1993; Eastwood et al. 1994; Jahier et al. 2001; Ogbonnaya et al. 2001; Paull et al. 1998; Romero et al. 1996; Slootmaker et al. 1974; Zhai et al. 2008). The various $\mathrm{Cre}$ genes do not provide resistance against all $\mathrm{CCN}$ species nor to all pathotypes within a species. Among them, Cre 1, 3, and 8 confer resistance to several Australian pathotypes and have successfully reduced $\mathrm{CCN}$ infestation to very low levels in that country (Lewis et al. 2009; Rathjen et al. 1998). The breeding program of USDA-ARS at Washington State University is currently screening wheat varieties and breeding lines for $\mathrm{CCN}$ resistance to the local pathotypes.

The cyst nematode genus, Heterodera, consisting of more than 60 species, is one of the earliest discovered genera of plant-parasitic nematodes (Wouts and Baldwin 1998). A complex of 12 Heterodera species parasitizing cereals and grasses were named as the $H$. avenae complex (Handoo 2002), among which $H$. avenae, H. filipjevi, and $H$. latipons have significant negative impacts on cultivated cereals (Nicol et al. 2007). H. avenae is widely distributed across Europe and the Mediterranean region, and was also reported in Asia, Australia, South Africa, and North and South America (Smiley et al. 2017). In the United States, it was first reported in 1974 in western Oregon and later in seven other western states including Washington (Jensen et al. 1975; Smiley 2009). H. filipjevi is widespread in Europe and the Mediterranean region, and has been reported in Asia 
and North America (Smiley et al. 2017). It was first detected in the United States in Oregon in 2008 (Smiley et al. 2008) and later in Washington in 2014 (Smiley and Yan 2014). H. latipons has been reported in the Mediterranean region, Europe, Asia, and North Africa, but not in the United States (Smiley et al. 2017). Extended surveys conducted in the European and Mediterranean countries revealed the widespread distribution of $\mathrm{CCN}$. The occurrence and distribution of $\mathrm{CCN}$ in other cereal production areas, such as North America, has not been thoroughly studied. Distribution surveys are critical if $\mathrm{CCN}$ is to be managed effectively.

Different CCN species and pathotypes within species may show different virulence reactions to the same host cultivar (Smiley and Yan 2014); thus species identification is essential for controlling $\mathrm{CCN}$ through host genetic resistance. Traditional methods of species identification based on morphology and morphometrics are timeconsuming and require highly specialized skills. Molecular characterization, which has been developed and refined in recent years, provides a more accurate and rapid alternative. Ribosomal DNA (rDNA) has been widely used for various taxonomic purposes including CCN species identification. The rDNA consists of the internal transcribed spacers (ITS1 and ITS2) and the 18S, 5.8S, and 28S rRNA genes (Ferris 1993). The 5.8S rRNA gene is highly conserved, while the $18 \mathrm{~S}$ and $28 \mathrm{~S}$ rRNA genes accumulated more variations during evolution. The ITS regions, which are under the least selection pressure, possess a relatively higher rate of variation and have been used as the ideal targets for phylogenetic studies. In this study, we directly sequenced the gene fragments of the ITS and/or 28S rRNA and compared the sequences to those of the identified species in the GenBank database in the National Center for Biotechnology Information (NCBI) to determine species matches.

Early investigations revealed the widespread occurrence of CCN in Washington State starting in 2007 (Kandel 2012). Surveys conducted in 2010 and 2011 showed extensive infestations in the higher precipitation areas of the Palouse region of eastern Washington, from southern Whitman County to Spokane County, along the Highway 195 corridor. $\mathrm{CCN}$ in these surveys were quantified by a commercial lab. More extended surveys through 2013 to 2016 of 244 fields throughout eastern Washington and the Palouse identified cysts from infested locations to the species level. We developed and optimized methods to extract DNA from a single cyst and used direct sequencing to identify the species. This report is the first detailed survey of $\mathrm{CCN}$ in North America.

\section{Materials and Methods}

Sampling procedure. Soil samples were collected in 2007, 2010, 2011, 2013, 2014, 2016, and 2017 from spring small grain fields in late June or early July, and winter wheat fields in late October or early November. Each sample consisted of a composite of 3 shovel slices about $15 \mathrm{~cm}$ deep and $2 \mathrm{~kg}$ in weight, near the roots of wheat, barley, or oat. The soil was collected into plastic sample bags and air-dried at room temperature until use. The geographic coordinates were recorded using GPS set to the World Geodetic System of 1984 (WGS84) datum.

Cyst quantification. Soil samples collected in 2007, 2010, and 2011 were submitted to the Western Laboratories, Parma, ID for quantification of cyst numbers. At Western Laboratories, nematodes were isolated as described by Smiley et al. (2011). Briefly, nematodes in both vermiform and encysted stages were collected by sieving. Cysts were crushed in a pestle to release eggs and larvae. The mixture was centrifuged at 3,200 rpm for $5 \mathrm{~min}$ and then with $\mathrm{MgSO}_{4}$ at the same speed for $4 \mathrm{~min}$. Floated eggs and juveniles were collected in a 50-ml tube and counted as eggs and juveniles per $500 \mathrm{ml}$.

Cyst isolation from soil. For samples collected in 2013 through 2017, the cyst isolation method was optimized based on the traditional sieving-decanting method described by Van Bezooijen (2006). Approximately $100 \mathrm{ml}$ of soil from each sample was dissolved with tap water and allowed to settle for $2 \mathrm{~min}$ for soil particle deposition. The supernatant containing the floating cysts was decanted into another container. The decanting was repeated three times and the final solution was passed through two layers of sieves $(250-\mu \mathrm{m}$-pore sieve at the bottom and 1-mm-pore sieve on the top) by high-pressure water spray. Cysts and other debris collected on the bottom sieve were vacuum-filtrated onto a 90-mm-diameter Whatman filter paper disk (GE Healthcare, Chicago, IL) and transferred to a $100 \times 15 \mathrm{~mm}$ petri dish (Fisher Scientific, Hampton, NH). Cysts were picked under a dissecting microscope for use in DNA extraction.

DNA extraction from single cyst. A single cyst was crushed between two glass slides and collected in a PCR tube with $10 \mu \mathrm{lmolec}-$ ular grade water. To each tube, $15 \mu$ l of lysis buffer $(500 \mathrm{mM} \mathrm{KCl}$, $100 \mathrm{mM}$ Tris- $\mathrm{HCl}, \mathrm{pH} 8.3,15 \mathrm{mM} \mathrm{MgCl} 2,10 \mathrm{mM}$ DTT, $4.5 \%$ Tween 20) were added and mixed. The samples were then frozen at $-20^{\circ} \mathrm{C}$ for $2 \mathrm{~h}$. Each thawed sample was mixed with 0.5 units of proteinase $\mathrm{K}$ (New England Biolabs, Ipswich, MA) and incubated $2 \mathrm{~h}$ at $56^{\circ} \mathrm{C}$, then $10 \mathrm{~min}$ at $95^{\circ} \mathrm{C}$ to inactivate proteinase $\mathrm{K}$. The lysis solution was centrifuged for $30 \mathrm{~s}$ at $13,000 \mathrm{rpm}$ and the supernatant was transferred to new tubes and stored at $-20^{\circ} \mathrm{C}$ for the PCR assay. From each infested location, we selected one cyst for DNA extraction.

Amplification and sequencing of the target gene fragments. ITS and 28S rRNA primers (Table 1) were used for polymerase chain reactions (PCR). The PCR reactions were carried out in $20 \mu \mathrm{l}$ reactions containing $1 \mu \mathrm{l}$ of the lysis supernatant containing cyst DNA, $0.5 \mu \mathrm{M}$ primers, $200 \mu \mathrm{M}$ dNTPs, $1 \times$ PCR buffer, and $0.5 \mathrm{U}$ of Taq DNA polymerase (New England Biolabs, Ipswich, MA) using the following PCR profile: initial denaturation at $95^{\circ} \mathrm{C}$ for $3 \mathrm{~min}$, followed by 35 cycles amplification at $95^{\circ} \mathrm{C}$ for $30 \mathrm{~s}, 53$ or $55^{\circ} \mathrm{C}$ for $30 \mathrm{~s}$ (according to the Ta value of specific primer sets listed in Table 1 ), $72^{\circ} \mathrm{C}$ for $1 \mathrm{~min}$, and a final extension at $72^{\circ} \mathrm{C}$ for $10 \mathrm{~min}$. All reactions were carried out on a T100 thermal cycler (Bio-Rad Laboratories, Hercules, CA). Two $\mu l$ of the amplification products were resolved on $1 \%$ (wt/vol) agarose gels. A 100-bp DNA ladder (New England Biolabs, Ipswich, MA) was used as the size marker. The remaining $18 \mu l$ of the amplification products were purified using a DNA Clean \& Concentration Kit (Zymo Research, Irvine, CA) following the manufacturer's instructions. The purified DNA fragments were sequenced from both ends by ELIM Biopharm, CA. All sequences were compared with those of identified species in the GenBank database using the BLAST function in NCBI to determine the species. ID thresholds are query cover above $90 \%$, and sequence identity above $98 \%$.

\section{Results}

Surveys of CCN and geographic distribution. In the surveys of 2007, 2010, and 2011 (Fig. 1), CCN was found in 35 locations out of 112. Geographic coordinates of the surveyed locations, infestation state, and species are listed in Supplementary Table S1. CCN was

Table 1. Primers used for sequencing the ITS-rDNA and 28S rRNA gene regions

\begin{tabular}{|c|c|c|c|c|c|}
\hline Target region & Primer & Sequences $\left(5^{\prime}-3^{\prime}\right)$ & Ta $\left({ }^{\circ} \mathbf{C}\right)$ & Product size (bp) & Reference \\
\hline \multirow[t]{2}{*}{ ITS } & TW81_F & GTTTCCGTAGGTGAACCTGC & \multirow[t]{2}{*}{55} & \multirow[t]{2}{*}{950} & \multirow{2}{*}{$\begin{array}{l}\text { Joyce et al. 1994; } \\
\quad \text { Rumpenhorst et al. } 2003\end{array}$} \\
\hline & AB28_R & ATATGCTTAAGTTCAGCGGGT & & & \\
\hline \multirow[t]{2}{*}{ 28S rRNA } & D2A_F & ACAAGTACCGTGAGGGAAAGTTG & \multirow[t]{2}{*}{53} & \multirow[t]{2}{*}{900} & \multirow[t]{2}{*}{ Vovlas et al. 2006} \\
\hline & D3B_R & TCGGAAGGAACCAGCTACTA & & & \\
\hline \multirow{2}{*}{ Heterodera avenae ITS } & HaITS-F6 & ATGCCCCCGTCTGCTGA & \multirow[t]{2}{*}{64} & \multirow[t]{2}{*}{242} & \multirow[t]{4}{*}{ Yan et al. 2013} \\
\hline & HaITS-R4 & GAGCGTGCTCGTCCAAC & & & \\
\hline \multirow[t]{2}{*}{ H. filipjevi ITS } & HfITS-F1 & CCCGTCTGCTGTTGAGA & \multirow[t]{2}{*}{58} & \multirow[t]{2}{*}{170} & \\
\hline & HfITS-R1 & ACCTCAGGCTTTTATTATCAC & & & \\
\hline
\end{tabular}


primarily found in the eastern most area of Washington State, along the Highway 195 corridor. In nine locations, the populations were greater than $1,000 \mathrm{cyst} / \mathrm{kg}$. Before 2014, the CCN infestation in Washington State was considered to be solely $H$. avenae. Species identification was not conducted for the 2007, 2010, and 2011 survey samples.

From 2013 to 2017, 244 fields in eastern Washington and the Palouse area were surveyed for the presence/absence of CCN (Figs. 2 and 3). Geographic coordinates of the surveyed fields and the infestation state and species are listed in Supplementary Tables S2 and S3.
Sampling sites were selected to cover the major wheat growing areas of eastern Washington.

In 2013, 49 fields were sampled and 16 (33\%) of them were infested with CCN. All locations were identified as $H$. avenae, except for the Colton site. In 2014, 75 fields were sampled and 12 (16\%) of them were infested. H. filipjevi was identified in Washington State later that year and the species identification method was developed (see below). In 2015, we went back to the CCN positive 2013 and 2014 survey samples and conducted the species identification.

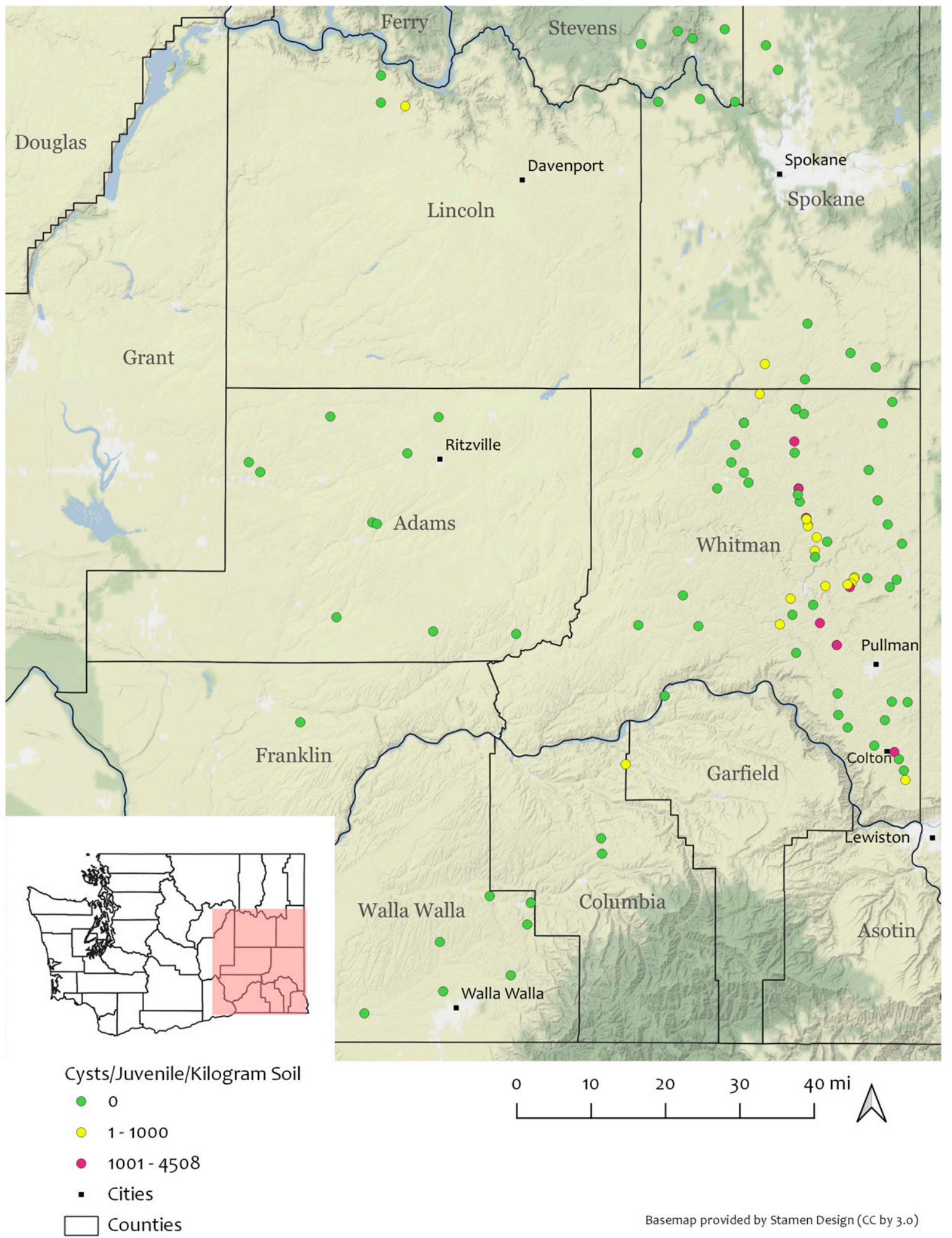

Fig. 1. Distribution of cereal cyst nematode (Heterodera spp.) from surveys in 2007, 2010, and 2011. Counts were made by Western Labs, but this method could not distinguish between $H$. avenae and $H$. filipjevi. Highway 195 runs between Spokane and Pullman. 
CCN from all locations were identified as $H$. avenae except for the Colton site.

In 2015, 53 sites were sampled and 20 (38\%) were infested. All were $H$. avenae except the Colton site and a site south of Uniontown, which were infested with $H$. filipjevi. In 2016, 53 fields were surveyed and $6(11 \%)$ were infested. In 2017, 14 locations were surveyed and $9(64 \%)$ were infested. CCN from all locations were identified as $H$. avenae except those surrounding Colton, which were
H. filipjevi. In all the sampled fields through the 5 years, about $26 \%$ were infested with $\mathrm{CCN}$.

CCN species identification. Four sets of previously reported primers were used in this study: ITS primers TW81 and AB28, 28S rRNA primers D2A and D3B, ITS $H$. avenae specific primers HaITS-F6 and R4, and ITS $H$. filipjevi specific primers HfITS-F1 and R1 (Table 1). The soil was collected from Colton wheat, barley, and oat fields, which had been previously identified as infested with

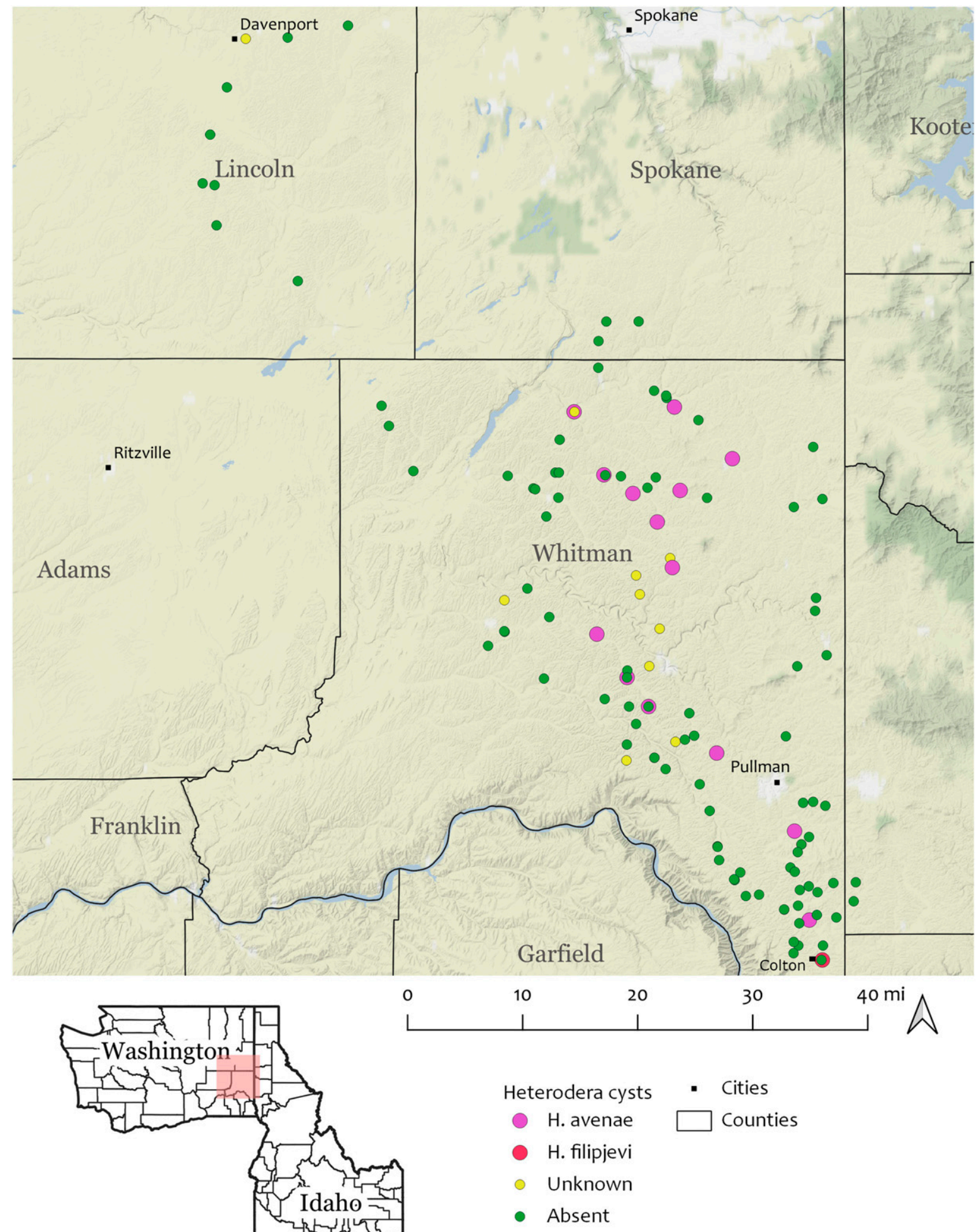

Basemap provided by Stamen Design (CC by 3.0)

Fig. 2. Distribution of Heterodera avenae and H. filipjevi from surveys of 2013 and 2014. Identifications were made from DNA sequencing of single cysts. Highway 195 runs between Spokane and Pullman. 
H. filipjevi with high population density. The root/soil mixture was processed with a soil DNA extraction kit (MoBio Power Soil, Qiagen, Inc., Carlsbad, CA) according to the manufacturer's instructions. The resulting DNA was used as controls to test the primers (Fig. 4). As shown in Figure 4, all the primers performed as expected. There were some nonspecific amplification products of the ITS primers between 600 and $800 \mathrm{bp}$, which were identified as fungal parasites by ITS sequencing. DNA was extracted from an individual cyst from each infested field and amplified with ITS and/or 28S rRNA primers (Fig. 5).
All amplicons were sequenced and BLASTed against those of the identified species in the GenBank database in NCBI. The sequences and BLAST information are presented in Supplementary Table S4.

We sampled only one cyst per soil sample for DNA extraction, which guaranteed a high success rate for sequencing; however, mixed infections can be missed with single cyst sequencing. For mixed infection detection, the species-specific primers HaITS-F6 and R4, and HfITS-F1 and R1 (Table 1) can be used on a larger sample. A large amount of CCN DNA can be extracted and mixed to serve as the

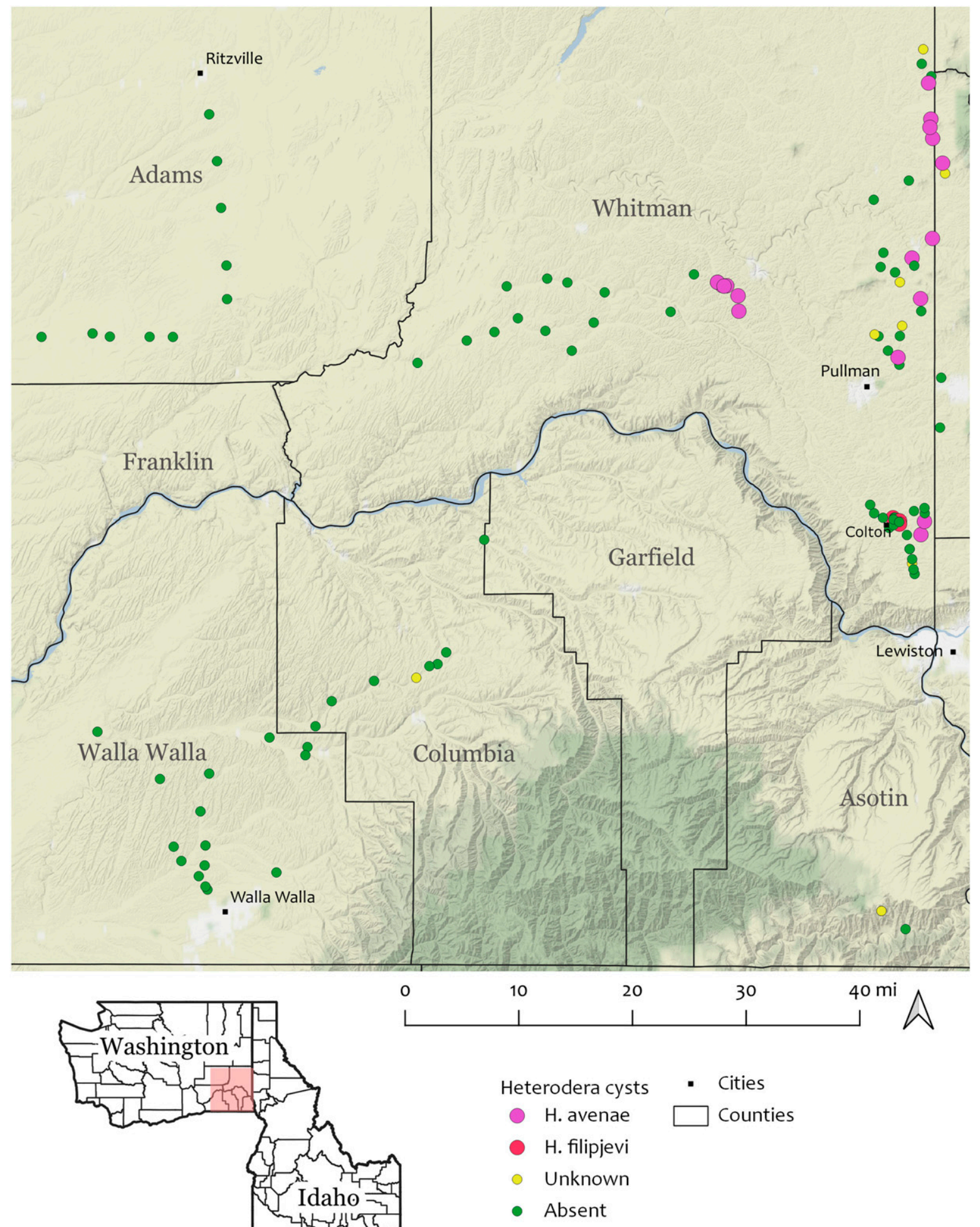

Basemap provided by Stamen Design (CC by 3.0)

Fig. 3. Distribution of Heterodera avenae and $\mathrm{H}$. filipjevi from surveys of 2015-2017. Identifications were made from DNA sequencing of single cysts. Highway 195 runs between Spokane and Pullman. 
DNA template. PCR reactions can be done using the species-specific primers separately. If both primer sets result in the expected amplicons, the infestation is a mixture of $H$. avenae and $H$. filipjevi. We have tested the soil samples from the Colton site using these primers and found that Colton site was dominant, if not purely infested, by $H$. filipjevi.

\section{Discussion}

Cyst nematode infestation is present along a north-south corridor roughly parallel to US 195 in Eastern Washington. Several locations
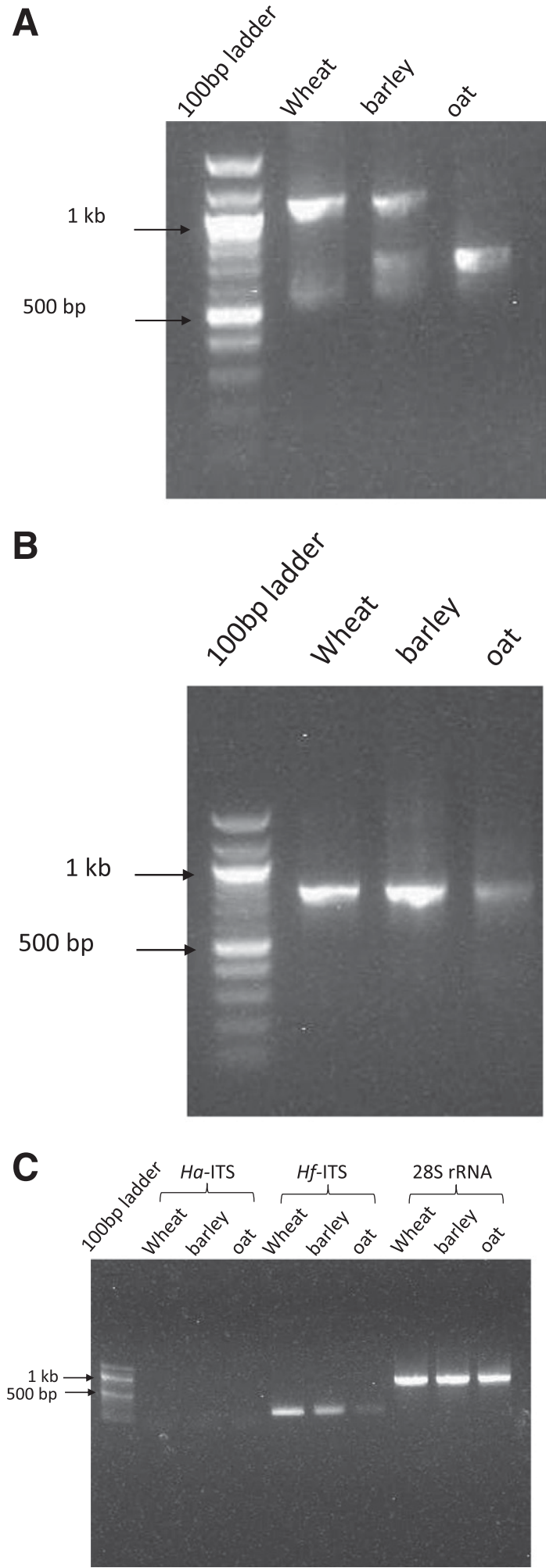

Fig. 4. Primers test with known CCN DNA controls. A) ITS primers; B) $28 \mathrm{~S}$ rRNA primers; C) ITS species-specific primers. had potentially yield damaging population levels. Cyst nematodes may be carried on farm equipment. These results show that management practices and small grain improvement programs targeted to the region need to consider the control of $\mathrm{CCN}$.

H. avenae was first reported in North America in Ontario, Canada in the 1930s (Chapman 1938), and by the 1960s, it had been detected across the province (Johnson and Fushtey 1966). The first report of H. avenae in the United States was in western Oregon in the 1970s (Jensen et al. 1975), and by the 1980s it had moved to the dryland wheat production area of northeastern Oregon (Hafez et al. 1992; Smiley et al. 2007). Subsequently, it was reported in California (Hackney 1981), Washington (Hafez and Golden 1984), Michigan (Graney 1985), Idaho (Hafez et al. 1992), Colorado, Montana, and Utah (Smiley et al. 2007). In 2008, H. filipjevi was first reported in North America in Oregon (Smiley et al. 2008), and later it was detected in eastern Washington (Smiley and Yan 2014) and Montana (Dyer et al. 2015). CCN was not considered a problem in eastern Washington until 2010. Surveys conducted in 2010 and 2011 showed extensive infestations in higher precipitation areas of the Palouse, from southern Whitman County to Spokane County, along the Highway 195 corridor. Thirty percent of the surveyed fields were infested. White female cysts were detected on spring wheat, with typical symptoms on roots. This region typically has a 3-year winter wheat/spring wheat/legume rotation. There were few detections in the drier area, in the winter wheat-summer fallow zone where winter wheat is grown every other year. We conducted this study to get a clearer picture of the $\mathrm{CCN}$ infestation in eastern Washington.

$\mathrm{CCN}$ suppresses wheat yield on a large scale. Although dependent on $\mathrm{CCN}$ population density, management practices, and other biotic and abiotic factors, the percentage of yield loss caused by CCN has been reported from 15 to $92 \%$ around the world, most commonly about 50\% (Smiley et al. 2017; Toumi et al. 2018). Generally speaking, the economic threshold is 3 nematodes, eggs plus juveniles, per gram of soil, which is approximately 1,400 nematodes per pound of soil (Smiley 2016). Smiley (2009) made an estimation of the impact of $H$. avenae on wheat production and profitability in the Pacific Northwest (PNW). Assuming only $0.04 \%$ of the wheat production area was infested with damaging levels of $\mathrm{CCN}$ and the overall yield suppression was only $10 \%$, yield loss in PNW, therefore, would be 21,000 tons and valued $\$ 3.4$ million. Of the 356 fields surveyed in this study, $28 \%$ were found infested with CCN. Yield loss due to $\mathrm{CCN}$ in the region may be much higher than presently estimated. Additional research on the economic threshold for $\mathrm{CCN}$ in the Pacific Northwest cropping systems is needed.

Among the current management strategies, breeding for resistant host cultivars constitutes the most efficient and cost-effective method to reduce the damage. Since 2011, we have focused on screening germplasm and varieties of spring wheat using the heavily infested field plot in Colton that could be planted in the spring after cysts

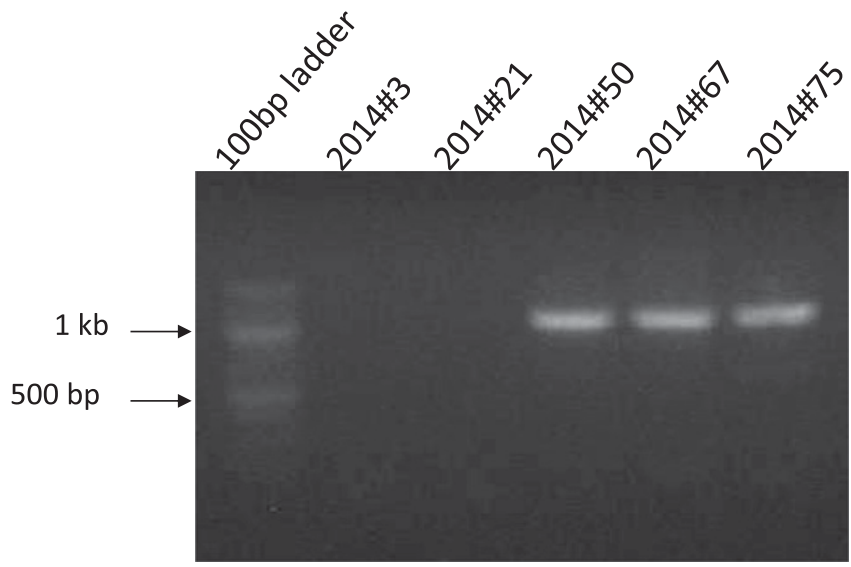

Fig. 5. ITS primers PCR amplicons of some samples form 2014 survey. Samples \#50 67 , and 75 had the DNA fragments at the right size. Samples \#3 and 21 didn't amplify, which was probably due to sampling of an older empty cyst. 
had hatched. This site was the first to be identified as infested with $H$. filipjevi in Washington. Both Heterodera species require a cold vernalization before hatching is induced. We then expanded resistance screening to the greenhouse by collecting infested field soil in the fall, keeping it at $4^{\circ} \mathrm{C}$ for 2 months, and then conducting greenhouse trials. This soil could be stored at $4{ }^{\circ} \mathrm{C}$ for over a year and remain infective. Up to now, we have screened over 1,000 breeding lines and cultivars in the greenhouse and identified about 200 lines with some resistance. However, wheat cultivars may show different virulence reactions to different $\mathrm{CCN}$ species. For example, the cultivar 'WB Rockland' is resistant to $H$. avenae, and the cultivar 'SY Steelhead' is resistant to $H$. filipjevi, but not vice-versa. This indicates the necessity of CCN species identification prior to development of resistant germplasm.

Subbotin et al. (2018) reported that the mitochondrial $\mathrm{COl}$ gene is another powerful DNA marker for $\mathrm{CCN}$ species identification because mitochondrial DNA evolves faster than the rRNA genes. They conducted phylogenetic analyses of $\mathrm{CO} 1$ genes from 147 nematode populations in 26 countries and obtained 220 new $C O 1$ gene sequences. Each species in the Avenae complex had a unique $\mathrm{COI}$ barcode that enables species identification. For future identification study, $\mathrm{CO} 1$ could serve as a substitute marker. According to their COl barcoding, $H$. avenae from the Palouse area belongs to the HavA 8 haplotype, and $H$. filipjevi belongs to the HfA4 haplotype.

Our study is the first detailed CCN distribution survey in the region of eastern Washington covering approximately $25,000 \mathrm{~km}^{2}$. To our knowledge, it is also the first detailed survey in any region in North America. We sampled 356 wheat and barley fields in total through the years 2007 to 2017, and the CCN from the infested locations were identified to species level. This survey builds the foundation of managing $\mathrm{CCN}$ through host genetic resistance and reducing the potential huge yield loss caused by $\mathrm{CCN}$.

\section{Acknowledgments}

We thank Dr. Richard Smiley for CCN sampling and results in 2007 and Dr. Richard Alan Rupp for drawing up the survey maps. We also thank Emily Klarquist, Patricia DeMacon, Tingting Liu, Dan Schlatter, and all the other members of the Garland-Campbell and Paulitz laboratories for their assistance.

\section{Literature Cited}

Alexandratos, N., and Bruinsma, J. 2012. World agriculture towards 2030/2050: The 2012 revision. Food and Agriculture Organization of the United Nations, Rome. ESA Working paper No. 12-03.

Asiedu, R., Fisher, J., and Driscoll, C. 1990. Resistance to Heterodera avenae in the rye genome of triticale. Theor. Appl. Genet. 79:331-336.

Barloy, D., Lemoine, J., Abelard, P., Tanguy, A. M., Rivoal, R., and Jahier, J. 2007. Marker-assisted pyramiding of two cereal cyst nematode resistance genes from Aegilops variabilis in wheat. Mol. Breed. 20:31-40.

Chapman, L. J. 1938. Oat nematodes on winter wheat. Sci. Agric. 18:527-529.

Delibes, A., Romero, D., Aguaded, S., Duce, A., Mena, M., Lopez-Braña, I., Andres, M. F., Martin-Sanchez, J. A., and García-Olmedo, F. 1993. Resistance to the cereal cyst nematode (Heterodera avenae Woll.) transferred from the wild grass Aegilops ventricosa to hexaploid wheat by a "steppingstone" procedure. Theor. Appl. Genet. 87:402-408.

Diekmann, F. 2009. Commodity of the quarter: Wheat. J. Agric. Food Inf. 10: 289-299.

Dyer, A. T., Al-Khafaji, R., Lane, T., Paulitz, T., Handoo, Z. A., Skantar, A. M., and Chitwood, D. J. 2015. First report of the cereal cyst nematode Heterodera filipjevi on winter wheat in Montana. Plant Dis. 99:1188.

Eastwood, R. F., Lagudah, E. S., and Appels, R. 1994. A directed search for DNA sequences tightly linked to cereal cyst nematode resistance genes in Triticum tauschii. Genome 37:311-319.

Ferris, V. R. 1993. Variation in spacer ribosomal DNA in some cyst-forming species of plant parasitic nematodes. Fundam. Appl. Nematol. 16:177-184.

Graney, L. S. O. 1985. Observations on the morphology of Heterodera carotae and Heterodera avenae in Michigan. J. Nematol. 17:519.

Hackney, R. W. 1981. Oat cyst nematode found in San Mateo county. Plant Pathology Rep. California Department of Food and Agriculture. 5:31.

Hafez, S. L., and Golden, A. M. 1984. First report of oat cyst nematode in eastern Washington. Plant Dis. 68:351

Hafez, S. L., Golden, A. M., Rashid, F., and Handoo, Z. 1992. Plant-parasitic nematodes associated with crops in Idaho and eastern Oregon. Nematropica 22:193-204.

Handoo, Z. A. 2002. A key and compendium to species of the Heterodera avenae group (Nematoda: Heteroderidae). J. Nematol. 34:250-262.
Hassan, G., Al-Assas, K., and Jamal, M. 2010. Damage potential and reproduction of Heterodera avenae on wheat under Syrian field conditions. Nematol. Mediterr. 38:73-78.

Holgado, R., Stoen, M., Magnusson, C., and Hammeraas, B. 2003. The occurrence and hosts of cereal cyst nematodes (Heterodera spp.) in Norway. Int. J. Nematol. 13:1-19.

Ibrahim, A. A. M., Al-Hazmi, A. S., Al-Yahya, F. A., and Alderfasi, A. A. 1999 Damage potential and reproduction of Heterodera avenae on wheat and barley under Saudi field conditions. Nematology 1:625-630.

Jahier, J., Abelard, P., Tanguy, M., Dedryver, F., Rivoal, R., Khatkar, S., Bariana, H., and Koebner, R. 2001. The Aegilops ventricosa segment on chromosome 2AS of the wheat cultivar 'VPM1'carries the cereal cyst nematode resistance gene Cre5. Plant Breed. 120:125-128.

Jensen, H. J., Eshtiaghi, H., Koepsell, P. A., and Goetze, N. 1975. The oat cyst nematode, Heterodera avenae, occurs in oats in Oregon. Plant Dis. Rep. 59:1-3.

Johnson, P. W., and Fushtey, S. G. 1966. The biology of the cyst nematode Heterodera avenae in Canada. Nematologica 12:630-636.

Joyce, S., Burnell, M., and Powers, T. O. 1994. Characterization of Heterorhabditis isolates by PCR amplification of segments of mtDNA and rDNA genes. J. Nematol. 26:260-270.

Kandel, S. 2012. A survey of root lesion and cereal cyst nematodes in the dryland wheat production areas of eastern Washington and resistance of Pacific northwest wheat varieties. M.S. thesis, Washington State University.

Lewis, J., Matic, M., and McKay, A. 2009. Success of cereal cyst nematode resistance in Australia: History and status of resistance screening systems. Pages 137-142 in: Cereal cyst nematodes: Status, research and outlook. Proceedings of the first workshop of the international cereal cyst nematode initiative, Antalya, Turkey.

Maqbool, M. A. 1988. Present status of research on plant parasitic nematodes in cereals and food and forage legumes in Pakistan. Pages 173-180 in: Nematodes parasitic to cereals and legumes in temperate semi-arid regions. International Center for Agricultural Research in the Dry Areas, Aleppo, Syria.

Mathur, B. N., Handa, D. K., Swarup, G., Sethi, C. L., Sharma, G. L., and Yadav, B. D. 1986. On the loss estimation and chemical control of 'Molya' disease of wheat caused by Heterodera avenae in India. Indian J. Nematol. 16:152-159.

Meagher, J. W. 1972. Cereal cyst nematode (Heterodera avenae Woll.): Studies on ecology and control in Victoria. Tech. Bull. 24. Victoria Department of Agriculture, Melbourne Australia.

Mor, M., Cohn, E., and Spiegel, Y. 1992. Phenology, pathogenicity and pathotypes of cereal cyst nematodes, Heterodera avenae and H. latipons (Nematoda: Heteroderidae) in Israel. Nematologica 38:494-501.

Namouchi-Kachouri, N., B'chir, M. M., and Hajji, A. 2007. Effect of initial populations of Heterodera avenae Woll. on wheat and barley yield components and on final nematode populations under Tunisian field conditions. Tunisian J. Plant Prot. 3:19-26.

Nicol, J. M., Elekcioglu, I. H., Bolat, N., and Rivoal, R. 2007. The global importance of the cereal cyst nematode (Heterodera spp.) on wheat and international approaches to its control. Commun. Agric. Appl. Biol. Sci. 72: 677-686.

Ogbonnaya, F. C., Seah, S., Delibes, A., Jahier, J., López-Braña, I., Eastwood, R. F., and Lagudah, E. S. 2001. Molecular-genetic characterisation of a new nematode resistance gene in wheat. Theor. Appl. Genet. 102:623-629.

Paull, J. G., Chalmers, K. J., Karakousis, A., Kretschmer, J. M., Manning, S., and Langridge, P. 1998. Genetic diversity in Australian wheat varieties and breeding material based on RFLP data. Theor. Appl. Genet. 96:435-446.

Peng, D., Zhang, D., Nicol, J. M., Chen, S., Waeyenberge, L., and Moens, M. 2007. Occurrence, distribution and research situation of cereal cyst nematode in China. Pages 350-351 in: Proceedings of the XVI international plant protection conference, Glasgow, UK.

Rathjen, A. J., Eastwood, R. F., Lewis, J. G., and Dube, A. J. 1998. Breeding wheat for resistance to Heterodera avenae in Southeastern Australia. Euphytica 100: $55-62$.

Romero, M., Andres, M., Lopez-Brana, I., and Delibes, A. 1996. A pathogenic and biochemical comparison of two Spanish populations of the cereal cyst nematode. Nematol. Mediterr. 24:235-244.

Rumpenhorst, H. J., Sturhan, D., Subbotin, S., and Moens, M. 2003. Molecular and morphological characterisation of the Heterodera avenae species complex (Tylenchida: Heteroderidae). Nematology 5:515-538.

Slootmaker, L., Lange, W., Jochemsen, G., and Schepers, J. 1974. Monosomic analysis in bread wheat of resistance to cereal root eelworm. Euphytica 23: 497-503.

Smiley, R., Marshall, J., and Yan, G. 2011. Effect of foliarly applied spirotetramat on reproduction of Heterodera avenae on wheat roots. Plan Dis. 95:983-989.

Smiley, R., Sheedy, J., Pinkerton, J., Easley, S., Thompson, A., and Yan, G. P. 2007. Cereal cyst nematode: distribution, yield reduction, and crop management strategies. Or. Agric. Exp. Stn. Spec. Rep. 1074:15-29.

Smiley, R. W. 2009. Occurrence, distribution and control of Heterodera avenae and $H$. filipjevi in the western USA. Pages 35-40 in: Cereal cyst nematodes: Status, research and outlook. Proceedings of the first workshop of the international cereal cyst nematode initiative, Antalya, Turkey. 
Smiley, R. W. 2016. Cereal cyst nematodes: Biology and management in Pacific Northwest wheat, barley, and oat crops. Pacific Northwest Extension Publication PNW620. Oregon State University.

Smiley, R. W., Dababat, A. A., Iqbal, S., Jones, M. G. K., Maafi, Z. T., Peng, D., Subbotin, S. A., and Waeyenberge, L. 2017. Cereal cyst nematodes: A complex and destructive group of Heterodera species. Plant Dis. 101:1692-1720.

Smiley, R. W., Ingham, R. E., Uddin, W., and Cook, G. H. 1994. Crop sequences for managing cereal cyst-nematode and fungal pathogens of winter-wheat. Plant Dis. 78:1142-1149.

Smiley, R. W., and Yan, G. 2014. Discovery of Heterodera filipjevi in Washington and comparative virulence with $H$. avenae on wheat. Plant Dis. 99:376-386.

Smiley, R. W., Yan, G. P., and Handoo, Z. A. 2008. First record of the cyst nematode Heterodera filipjevi on wheat in Oregon. Plant Dis. 92:1136.

Subbotin, S. A., Toumi, F., Elekçioğlu, I. H., Waeyenberge, L., and Tanha Maafi, Z. 2018. DNA barcoding, phylogeny and phylogeography of the cyst nematode species of the Avenae group from the genus Heterodera (Tylenchida: Heteroderidae). Nematology 20:671-702.
Toumi, F., Waeyenberge, L., Viaene, N., Dababat, A. A., Nicol, J. M., Ogbonnaya, F., and Moens, M. 2018. Cereal cyst nematodes: importance, distribution, identification, quantification, and control. Eur. J. Plant Pathol. 150:1-20.

Van Bezooijen, J. 2006. Extraction from soil and other substrates. Pages 30-33 in: Methods and Techniques for Nematology.Wageningen University, The Netherlands.

Vovlas, N., Baldwin, J., Sturhan, D., Chizhov, V., and Subbotin, S. 2006. Phylogenetic analysis of Tylenchida Thorne, 1949 as inferred from D2 and D3 expansion fragments of the 28S rRNA gene sequences. Nematology 8 : 455-474.

Wouts, W. M., and Baldwin, J. G. 1998. Taxonomy and identification. Pages 83-122 in: The Cyst Nematodes. Springer, Netherlands.

Yan, G., Smiley, R. W., Okubara, P. A., and Skantar, A. M. 2013. Species-specific PCR assays for differentiating Heterodera filipjevi and H. avenae. Plant Dis. 97 1611-1619.

Zhai, X. G., Zhao, T., Liu, Y. H., Long, H., Deng, G. B., Pan, Z. F., and Yu, M. Q 2008. Characterization and expression profiling of a novel cereal cyst nematode resistance gene analog in wheat. Mol. Biol. 42:960-965. 